\title{
Eco-friendly dye for cotton yarn
}

\section{RAJASHREE PHUKON}

Received: 18.12.2013; Accepted: 05.11.2014

Author for correspondence:

\section{RAJASHREE PHUKON}

\section{Sibsagar Girls' College,}

SIVASAGAR (ASSAM) INDIA

Email: rajashreephukan@yahoo.

com
ABSTRACT : Considering the growing importance of natural colourants all over the world, the study was undertaken with an aim to develop the dyeing conditions of the bark of Eugenia jambolana Lam. (black plum) dye on cotton yarn. The natural mordant used in the research work was Aluminium Potassium Sulphate $\left(\mathrm{AlK}\left(\mathrm{SO}_{4}\right)_{2}\right)$ for better fixation of the dye. The dye was extracted by alkaline method and the extraction time was optimized from the optical density values. The pre-mordanting method was used for mordanting the yarn. Shades of different colours, ranging from yellow to brown were obtained from the dye on cotton yarn. Fastness grades rated for all the samples were found to be good. The dye was found to be an ideal source which could be adopted at commercial level.

KEY WORDS: Cotton yarn, Natural colourants, Eco-friendly

口 HOW TO CITE THIS PAPER : Phukon, Rajashree (2014). Eco-friendly dye for cotton yarn. Asian J. Home Sci., 9 (2) : 587589. 